\title{
SCREENING PENANDA MIKROSATELIT Shorea cUrtisii TERHADAP JENIS-JENIS SHOREA PENGHASIL TENGKAWANG
}

(Screening of microsatellite primers of Shorea curtisii for Shorea spp. producing tengkawang oil)

\author{
I.L.G. Nurtjahjaningsih, A.Y.P.B.C. Widyatmoko, P. Sulistyawati dan A. Rimbawanto \\ Balai Besar Penelitian Bioteknologi dan Pemuliaan Tanaman Hutan \\ E-mail: iluh_nc@yahoo.com
}

Tanggal diterima: 28 Februari 2012; Direvisi: 26 Maret 2012; Disetujui terbit: 26 Juni 2012

\begin{abstract}
Screening primer is an effective method to develop microsatellite markers from related taxa. Aim of this study was to develop microsatellite markers of four Shorea producing tengkawang oil, i.e. Shorea gysbertiana, Shorea macrophylla, Shorea pinanga and Shorea stenoptera by screening microsatellite primers of Shorea curtisii. Leaf samples of the four Shorea were collected from nursery at Center for Forest Biotechnology and Tree Improvement Research in Yogyakarta. Four microsatellite primers of S. curtisii i.e. Shc-1, Shc-2, Shc-7 and Shc-9 had been used to screen. Results showed that numerous alleles were shared among the Shorea. The expected heterozygosity (HE) for locus Shc-1 ranged between 0.594 and 0.722; locus Shc-2 ranged between 0.219 and 0.611; locus Shc-7 ranged between 0.594 and 0.778; and locus Shc-9 ranged between 0.594 and 0.844. Coefficient of inbreeding (FIS) value was low and it was insignificant deviated from Hardy-Weinberg Equilibrium (HWE) at almost all loci except Shc-1 of S. pinanga. A dendrogram showed two clusters; S. gysbertsiana and S. macrophylla represented in one cluster, while S. pinanga and S. stenoptera represented in another cluster. Therefore the developed microsatellite markers are possible to be applied for studying population genetics and mating system of these species.
\end{abstract}

Key words: screening microsatellite, genus Shorea, shared allele, expected heterozygosity, coefficient of inbreeding

\begin{abstract}
ABSTRAK
Metode seleksi primer merupakan metode yang efektif untuk mengembangkan penanda mikrosatelit dari jenis yang mempunyai kekerabatan dekat dalam suatu sistem taksonomi. Tujuan penelitian ini adalah mengembangkan penanda mikrosatelit pada jenis Shorea penghasil tengkawang yaitu Shorea gysbertiana, Shorea macrophylla, Shorea pinanga dan Shorea stenoptera menggunakan metode seleksi primer mikrosatelit dari Shorea curtisii. Contoh daun dari empat jenis Shorea dikumpulkan dari persemaian di Balai Besar Penelitian Bioteknologi dan Pemuliaan Tanaman hutan, Yogyakarta. Amplifikasi empat penanda mikrosatelit S. curtisii yaitu Shc-1, Shc-2, Shc-7 dan Shc-9 diuji pada empat jenis Shorea tersebut. Hasil menunjukkan bahwa sejumlah allele merupakan allele bersama antar jenis Shorea yang diuji. Nilai heterozigositas harapan $\left(H_{\mathrm{E}}\right)$ per lokus beragam, pada lokus Shc-1 berkisar antara 0,594 dan 0,722; lokus Shc-2 berkisar antara 0,219 dan 0,611;lokus Shc-7 berkisar antara 0,594 dan 0,779; lokus Shc-9 berkisar antara 0,594 dan 0,844 . Koefisien inbreeding $\left(F_{\text {IS }}\right)$ mempunyai nilai rendah dan tidak nyata menyimpang dari hukum keseimbangan Hardy-Weinberg pada hampir semua lokus kecuali lokus Shc-1 pada S. pinanga. Dendrogram membentuk dua kelompok: S. gysbertsiana dan S. macrophylla membentuk satu kelompok, sedangkan S. stenoptera dan $S$. pinanga membentuk satu kelompok yang lain. Penanda mikrosatelit yang telah dikembangkan dapat digunakan untuk studi genetik populasi dan sistem perkawinan pada jenis Shorea yang diuji.
\end{abstract}

Kata Kunci: seleksi mikrosatelit, genus Shorea, allele bersama, heterozigositas harapan, koefisien inbreeding

\section{PENDAHULUAN}

Mikrosatelit atau simple sequence repeat (SSR) merupakan sekuen penanda DNA bersifat ko-dominan dan banyak dijumpai hampir di semua organisme yang mempunyai inti sel sejati (eukaryote). Penanda DNA ini mempunyai tingkat keragaman genetik yang tinggi sehingga dapat digunakan untuk analisis genetik populasi, aliran gene (geneflow), sebaran serbuk sari, analisis tetua, membedakan jenis dan varietas 
dengan hasil yang akurat (Dow dan Ashley 1998; Rahman dan Rajora 2002) .

Ada beberapa metode untuk mengembangkan penanda mikrosatelit, misalnya pustaka pengkayaan DNA (DNA enrichment library) dan isolasi sekuens mikrosatelit. Namun demikian, pengembangan penanda dengan metode tersebut memerlukan biaya, tenaga dan waktu. Metode seleksi primer memberikan alternatif untuk mengembangkan penanda mikrosatelit dengan lebih menghemat biaya, waktu dan tenaga. Selain itu, metode seleksi primer juga mempunyai keberhasilan lebih tinggi pada jenis yang berkerabat dekat dan sudah diterapkan pada beberapa tanaman hutan baik konifer misalnya pada genera Pinus, Picea dan Pseudostuga yang dikembangkan dari Pinus strobus (Echt dkk. 1999), maupun daun lebar misalnya pada Shorea parvifolia yang dikembangkan dari Shorea leprosula (Lee dkk.2004).

\section{Shorea penghasil tengkawang} (Dipterocarpaceae) seperti S. gysbertsiana, S. macrophylla, S. pinanga dan S. stenoptera mempunyai nilai ekonomi yang tinggi untuk kayu maupun minyak tengkawang. Strategi pemuliaan untuk empat jenis Shorea tersebut telah ditetapkan untuk meningkatkan produktifitas kayu maupun minyaknya. Identifikasi jenis dan populasi menggunakan penanda mikrosatelit memberikan informasi akurat dan menjadi informasi penting dalam mendukung program pemuliaan maupun konservasi untuk empat jenis Shorea tersebut. Namun demikian penanda mikrosatelit untuk empat jenis ini belum dikembangkan.

Tujuan penelitian ini adalah mengembangkan penanda mikrosatelit pada empat jenis Shorea penghasil tengkawang menggunakan metode seleksi primer mikrosatelit dari S. curtisii. Hasil penelitian ini diharapkan dapat digunakan untuk mendukung strategi konservasi dan pemuliaan jenis-jenis tersebut.

\section{BAHAN DAN METODE}

\section{A. Koleksi materi genetik}

Contoh daun bibit S. gysbertsiana, S. macrophylla, S. pinanga dan S. stenoptera dikumpulkan secara acak dari persemaian Balai Besar Penelitian Bioteknologi dan Pemuliaan Tanaman Hutan Yogyakarta. Bibit tersebut berasal dari populasi alam di Kalimantan Barat dan Kalimantan Tengah serta kebun percobaan Haurbentes, Jawa Barat. Jumlah contoh daun yang digunakan dalam penelitian ini sebanyak 16 daun. Contoh daun tersebut dikemas dalam amplop yang telah diberi silica gel dan disimpan pada suhu ruang sampai dilakukan ekstraksi DNA.

\section{B. Ekstraksi DNA dan analisis mikrosatelit}

Contoh daun segar seberat $100 \mathrm{mg}$ dihaluskan menggunakan mesin penghalus daun 
(minibead), kemudian proses ekstraksi DNA dilakukan menggunakan metode CTAB (Shiraishi dan Watanabe 1995).

Penanda mikrosatelit pada jenis Shorea penghasil tengkawang dikembangkan menggunakan metode seleksi primer mikrosatelit dari Shorea curtisii yaitu Shc-1, Shc-2, Shc-7 dan Shc-9 (Ujino dkk. 1998). Sekuen primer tersebut disajikan pada Tabel 1. Proses PCR dilakukan menggunakan thermocycler GeneAmp9700 (Applied Biosystem). Suhu pemanasan awal $94^{\circ} \mathrm{C}$ selama 10 menit, diikuti dengan 10 siklus reaksi yang masing-masing terdiri dari reaksi denaturasi DNA (suhu $94^{\circ} \mathrm{C}$ selama 30 detik), reaksi penempelan primer (annealing) mengikuti protokol touchdown (suhu $65^{\circ}-55^{\circ} \mathrm{C}$ selama 30 detik) dan pemanjangan DNA (suhu $72^{\circ} \mathrm{C}$ selama 60 detik). Kemudian diikuti 25 siklus reaksi yang terdiri dari reaksi denaturasi DNA (suhu $94^{\circ} \mathrm{C}$ selama 30 detik), reaksi penempelan primer (suhu $55^{\circ} \mathrm{C}$ selama 30 detik), pemanjangan DNA (suhu $72^{\circ} \mathrm{C}$ selama 60 detik). Siklus PCR diakhiri pada suhu $72^{\circ} \mathrm{C}$ selama 1 menit untuk melengkapi proses pemanjangan. Elektroforesis berbasis kapiler menggunakan mesin gene analyzer ABI 3100 Avant (Applied Biosystem). Fragment DNA dianalisa menggunakan genemapper (Applied Biosystem).

Tabel 1. Sekuen primer dan motif ulangan mikrosatelit pada Shorea curtisii (Ujino dkk. 1998)

\begin{tabular}{|c|c|c|c|c|c|}
\hline $\begin{array}{l}\text { Nama } \\
\text { lokus }\end{array}$ & Sekuen basa (5’-3’) & Motif ulangan & $\begin{array}{c}\text { T. ann } \\
\left({ }^{\circ} \mathrm{C}\right)\end{array}$ & $N_{\mathrm{A}}$ & $H_{\mathrm{E}}$ \\
\hline Shc-1 & GCTAT TGGCA AGGAT GTTCA CTTAT GAGAT CAATT TGACA G & $(\mathrm{CT})_{8}(\mathrm{CA})_{10} \mathrm{CT}(\mathrm{CA})_{4} \mathrm{CTCA}$ & 56 & 20 & 0,922 \\
\hline Shc-2 & CACGC TTTCC CAATC TGTCAAGA GCAGA ATCCA G & $(\mathrm{CT})_{2} \mathrm{CA}(\mathrm{CT})_{5}$ & 54 & 2 & 0,180 \\
\hline Shc-7 & ATGTC CATGT TTGAG TGCATGG ACATA AGTGG ATG & $\begin{array}{l}(\mathrm{CT})_{8} \mathrm{CA}(\mathrm{CT})_{5} \mathrm{CACCC} \\
(\mathrm{CTCA})_{3} \mathrm{CT}(\mathrm{CA})_{10}\end{array}$ & 54 & 11 & 0,810 \\
\hline Shc-9 & TTTCT GTATC CGTGT GTTGGCGATT AAGCG GACCT CAG & $(\mathrm{CT})_{12}$ & 54 & 9 & 0,818 \\
\hline
\end{tabular}

Keterangan: T. ann: suhu penempelan primer, $N_{\mathrm{A}}$ : jumlah allele yang terdeteksi, $H_{\mathrm{E}}$ : Heterozigositas harapan per lokus

\section{Analisis data}

Parameter keragaman genetik per lokus yang digunakan dalam penelitian ini adalah jumlah allele yang terdeteksi $\left(\mathrm{N}_{\mathrm{a}}\right)$, nilai heterozigositas harapan $\left(H_{\mathrm{E}}\right)$ dan koefiesien inbreeding $\left(F_{\text {IS }}\right)$. Parameter tersebut dihitung menggunakan program GENALEX 6 (Peakall dan Smouse, 2006). Berdasarkan program tersebut, nilai signifikansi $F_{\text {IS }}$ yang menyimpang dari hukum keseimbangan Hardy Weinberg diuji menggunakan test $\chi^{2}$.

Nilai $H_{\mathrm{E}}$ (Peakall dan Smouse, 2006) diduga menggunakan persamaan:

$$
H_{\mathrm{E}}=1-\sum_{\mathrm{pi}}^{2}
$$

dengan pi merupakan frekuensi allele ke-i pada suatu populasi. 
sedangkan nilai $F_{\text {IS }}$ (Peakall dan Smouse, 2006) menggunakan persamaan:

$$
F_{\mathrm{IS}}=\frac{H_{\mathrm{E}}-H_{\mathrm{O}}}{H_{\mathrm{E}}}=1-\left(\frac{H_{\mathrm{O}}}{H_{\mathrm{E}}}\right)
$$

dengan nilai $H_{\mathrm{E}}$ diperoleh dari persamaan diatas, $H_{\mathrm{O}} \quad$ merupakan heterozigositas yang teramati. Nilai $H_{\mathrm{O}}$ dapat diperoleh menggunakan persamaan:

$$
H_{\mathrm{O}}=1-\sum_{\mathrm{i}=1} \sum_{\mathrm{j}=1} \mathrm{Pij}
$$

dengan Pij merupakan frekuensi genotipe yang homozigot.

Dendrogram disusun berdasarkan parameter jarak genetik per lokus (Da; Nei dkk. 1983) menggunakan metode UPGMA dengan 1.000 kali bootstrap. Dendrogram tersebut dianalisis menggunakan software POPTREE2 (Takezaki dkk. 2010).

\section{HASIL DAN PEMBAHASAN}

\section{A. Hasil}

\section{Allele bersama antar jenis Shorea penghasil tengkawang}

Ukuran allele yang terdeteksi pada jenis S. gysbertsiana, S. macrophylla, S. pinanga dan S. stenoptera dan pada lokus Shc-1, Shc-2, Shc7 dan Shc-9 disajikan pada Tabel 2. Beberapa allele merupakan allele bersama antar jenis Shorea yang diuji maupun S. curtisii. Allele 135 (Shc-2) merupakan allele bersama antara jenis Shorea yang diuji. Allele 152 (lokus Shc1) merupakan allele bersama antara S.curtisii, $S$. gysbertsiana dan S. macrophylla. Sedangkan allele 143 dan 145 (lokus Shc-1); 155 (lokus Shc-2); 197 (lokus Shc-9) merupakan allele bersama antara S. pinanga dan S. stenoptera.

Tabel 2. Ukuran allele mikrosatelit (bp) pada Shorea curtisii (Ujino dkk. 1998) dan empat jenis Shorea penghasil tengkawang

\begin{tabular}{|l|l|l|l|l|l|}
\hline \multicolumn{1}{|c|}{ Lokus } & S.curtisii & \multicolumn{1}{|c|}{ S. gysbertsiana } & \multicolumn{1}{c|}{ S. macrophylla } & \multicolumn{1}{c|}{ S. pinanga } \\
\hline Shc-1 & 152 & $152,169,179,187$ & $152,155,167,187$ & $143,145,157$ & $143,145,149$ \\
\hline Shc-2 & 149 & 131,135 & $135,143,153$ & $135,155,157$ & $135,147,155$ \\
\hline Shc-7 & 169 & $158,161,169,184$ & $152,154,165,179$ & $152,154,158,161,208$ & $154,158,161$ \\
\hline Shc-9 & 197 & $179,181,183,189,191,202,204$ & $183,187,189$ & $185,187,197$ & $183,187,189,197$ \\
\hline
\end{tabular}

Keragaman genetik per lokus setiap jenis Shorea

Tabel 3 menunjukkan parameter keragaman genetik per lokus per jenis Shorea yaitu jumlah allele yang terdeteksi $\left(N_{\mathrm{a}}\right)$, nilai heterozigositas harapan $\left(H_{\mathrm{E}}\right)$ dan koefisien inbreeding $\left(F_{\text {IS }}\right)$. Jumlah allele $\left(N_{\mathrm{a}}\right)$ berkisar antara 2 (lokus Shc-2- S. gysbertsiana) dan 7 allele (lokus Shc-9- S. gysbertsiana). Nilai heterozigositas harapan $\left(H_{\mathrm{E}}\right)$ berkisar antara 0,219 (lokus Shc-2-S. gysbertsiana) dan 0,844 (lokus Shc-9-S. gysbertsiana). Nilai koefisien 
inbreeding $\left(F_{\mathrm{IS}}\right)$ tidak signifikan pada setiap lokus setiap jenis kecuali pada lokus Shc-1 pada jenis S. pinanga.

Tabel 3. Parameter keragaman genetik per lokus per jenis Shorea

\begin{tabular}{|l|l|l|l|l|l|l|}
\hline Lokus & Jenis Shorea & $\mathrm{N}$ & $\mathrm{Na}$ & $H_{\mathrm{E}}$ & \multicolumn{2}{|l}{$F_{\mathrm{IS}}$} \\
\hline Shc-1 & S. gysbertsiana & 4 & 4 & 0,722 & 0,538 & $\mathrm{~ns}$ \\
\hline Shc-2 & S. gysbertsiana & 4 & 2 & 0,219 & $-0,143$ & $\mathrm{~ns}$ \\
\hline Shc-7 & S. gysbertsiana & 4 & 4 & 0,722 & $-0,385$ & $\mathrm{~ns}$ \\
\hline Shc-9 & S. gysbertsiana & 4 & 7 & 0,844 & $-0,185$ & $\mathrm{~ns}$ \\
\hline Shc-1 & S. macrophylla & 4 & 4 & 0,656 & 0,238 & $\mathrm{~ns}$ \\
\hline Shc-2 & S. macrophylla & 4 & 3 & 0,406 & $-0,231$ & $\mathrm{~ns}$ \\
\hline Shc-7 & S. macrophylla & 4 & 4 & 0,667 & $-0,500$ & $\mathrm{~ns}$ \\
\hline Shc-9 & S. macrophylla & 4 & 3 & 0,625 & 0,200 & $\mathrm{~ns}$ \\
\hline Shc-1 & S. pinanga & 4 & 3 & 0,625 & 1,000 & $*$ \\
\hline Shc-2 & S. pinanga & 4 & 3 & 0,611 & $-0,636$ & $\mathrm{~ns}$ \\
\hline Shc-7 & S. pinanga & 4 & 5 & 0,778 & $-0,286$ & $\mathrm{~ns}$ \\
\hline Shc-9 & S. pinanga & 4 & 3 & 0,594 & 0,579 & $\mathrm{~ns}$ \\
\hline Shc-1 & S. stenoptera & 4 & 3 & 0,594 & 0,579 & $\mathrm{~ns}$ \\
\hline Shc-2 & S. stenoptera & 4 & 3 & 0,594 & $-0,684$ & $\mathrm{~ns}$ \\
\hline
\end{tabular}

\begin{tabular}{|c|c|c|c|c|c|c|}
\hline Shc-7 & S. stenoptera & 4 & 3 & 0,594 & 0,579 & ns \\
\hline Shc-9 & S. stenoptera & 4 & 4 & 0,656 & 0,238 & ns \\
\hline
\end{tabular}

Dendrogram disusun berdasarkan jarak genetik untuk menunjukkan hubungan kekerabatan secara genetik antar empat jenis Shorea penghasil tengkawang (Gambar 1). Empat jenis Shorea tersebut terpisah secara jelas dan membentuk dua kelompok; kelompok pertama terdiri dari $S$. gysbertsiana dan $S$. macrophylla dan kelompok kedua terdiri dari $S$. stenoptera dan S.pinanga. Sub kelompok $S$. stenoptera dan $S$. pinanga terpisah secara jelas dengan interval konfiden $97 \%$ berdasarkan 1,000 kali bootstrap.

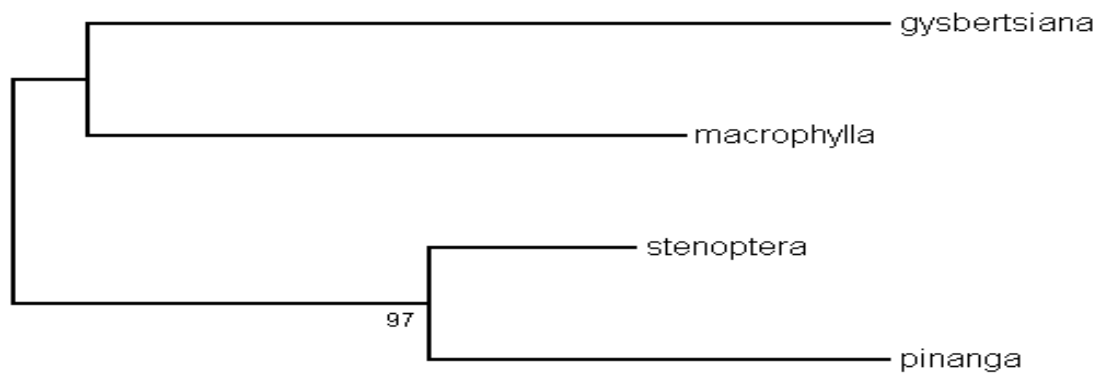

Gambar 1. Dendrogram menunjukkan kekerabatan antar empat jenis Shorea penghasil tengkawang dengan skala jarak genetik dan interval konfiden boostrap

Keterangan: gysbertsiana: Shorea gysbertsiana, macrophylla: Shorea macrophylla, pinanga: Shorea pinanga, stenoptera: Shorea stenoptera

\section{B. Pembahasan}

Hal yang paling menguntungkan saat mengembangkan penanda mikrosatelit melalui metode seleksi primer adalah dapat menghemat tenaga, waktu dan biaya. Pada umumnya keberhasilan metode seleksi primer pada jenis daun lebar mempunyai tingkat yang cukup tinggi, misalnya seleksi primer dari Shorea 
leprosula ke S. parvifolia keberhasilannya jumlah allele bersama berkisar antara 1-4 allele. mencapai 80\% (Lee dkk. 2004). Bahkan hampir Allele bersama juga ditunjukkan pada jenis semua penanda mikrosatelit yang Pinus yaitu berkisar antara 1-7 allele (Echt dkk. dikembangkan dari S. curtisii dapat digunakan 1999).

pada 30 jenis Dipterocarpaceae lain (Ujino dkk. Jumlah allele yang terdeteksi per lokus 1998). Pada penelitian ini keberhasilan metode setiap jenis Shorea cukup tinggi, berkisar antara seleksi primer mikrosatelit dari Shorea curtisii 2 (lokus Shc-2 pada S. gysbertsiana) sampai mencapai $100 \%$ pada empat jenis Shorea dengan 7 (lokus Shc-9 pada S. gysbertsiana). penghasil tengkawang yaitu S. gysbertsiana, Pada lokus yang sama yaitu Shc-2 dan Shc-9 S.macrophylla, S.stenoptera dan S. pinanga. pada S. curtisii, jumlah allele masing-masing Keberhasilan metode seleksi primer juga sebanyak 2 dan 9 (Ujino dkk. 1998). Tingkat dilaporkan pada jenis konifer. Semua penanda polimorfisme allele juga cukup tinggi, nilai $H_{\mathrm{E}}$ mikrosatelit (100\%) pada $\quad P$. strobus per lokus berkisar antara 0,219 (lokus Shc-2 teramplifikasi pada P. lambertiana karena dua pada S. gysbertsiana) dan 0,844 (lokus Shc-9 jenis tersebut termasuk dalam satu subsection stobi sedangkan keberhasilan seleksi primer $P$. strobus terhadap $P$. cembra hanya $86 \%$ karena dua jenis tersebut berbeda subsection; $P$. cembra termasuk dalam subsection cembrae (Echt dkk.1999). Namun demikian, banyak penelitian menunjukkan bahwa metode seleksi primer umumnya sulit diterapkan pada jenis konifer karena jenis ini mempunyai ukuran DNA besar; misalnya keberhasilan metode seleksi primer pada $P$. pinaster dari $P$. halepensis hanya 4\% (Mariette dkk. 2001). Oleh karena susunan sekuen basa berbeda-beda untuk setiap individu maka dalam satu jenis yang sama pun metode seleksi primer tidak dapat diaplikasikan (Ujino dkk. 1998).

Adanya allele bersama menunjukkan pada $S$. gysbertsiana). Hal yang sama juga dilaporkan pada $S$. curtisii bahwa nilai $H_{\mathrm{E}}$ berkisar antara 0,180 (lokus Shc-2) sampai 0,818 (lokus Shc-9) (Ujino dkk. 1998). Selain itu, hampir semua lokus di setiap jenis mempunyai nilai inbreeding $\left(F_{\text {IS }}\right)$ yang tidak nyata menyimpang dari hukum keseimbangan Hardy Weinberg. Hal ini menunjukkan tidak adanya kemungkinan null allele pada lokuslokus tersebut kecuali lokus Shc-1. Indikasi null allele terlihat di lokus Shc-1 yang menunjukkan nilai $F_{\text {IS }}$ yang cenderung tinggi pada semua jenis; namun nilainya tidak signifikan kecuali pada S. pinanga. Null allele adalah amplifikasi allele yang sebenarnya homozigot tapi menunjukkan allele heterozigot karena mutasi gen atau suhu annealing yang tidak sesuai pada kedekatan antar jenis. Pada penelitian ini, proses PCR. Null allele sangat mengganggu 
proses genotyping karena menyebabkan kesalahan pembacaan allele sehingga tidak dapat digunakan untuk analisis genetik (Moriguchi dkk.2003). Adanya indikasi null allele pada Shc-1 tidak dilaporkan pada jenis $S$. curtisii (Ujino dkk. 1998). Selain itu untuk membuktikan indikasi null allele tersebut dapat ditelusuri dengan menambah jumlah sampel yang diuji atau membandingkan amplifikasi allele antara genotype pohon induk dan anakannya. Apabila target allele teramplifikasi pada anakan namun tidak teramplifikasi pada pohon induk kemungkinan allele tersebut adalah null.

Dendrogram (Gambar 1) menunjukkan kedekatan genetik antar empat jenis Shorea yang diuji. Berdasarkan analisis RAPD (Random Amplified Polymorphic DNA) yang telah dilakukan juga menunjukkan pola kelompok (cluster) yang sama dengan hasil penelitian ini (data tidak dipublikasi). Berdasarkan frekuensi allele per lokus pada setiap jenis Shorea, dendrogram membentuk satu kelompok antara S. gysberstiana dan $S$. macrophylla, sedangkan S. stenoptera dan $S$. pinanga membentuk satu kelompok yang lain, dengan jenis-jenis dalam kelompok yang sama mengindikasikan kedekatan secara genetik. Informasi tersebut dapat digunakan untuk meningkatkan keberhasilan proses persilangan (hibridisasi) antar jenis yang merupakan salah satu strategi pada program pemuliaan pohon untuk mendapatkan gabungan sifat antar jenis yang diinginkan dan sudah diterapkan misalnya pada Acacia mangium dan A. auriculiformis (Rimbawanto dkk. 1996). Selain dalam satu kelompok, kedekatan genetik juga ditunjukkan pada jenis yang ada di luar kelompok namun letak sub kelompok saling berdekatan yang pada penelitian ini ditunjukkan pada sub kelompok $S$. macrophylla dan S. stenoptera (Gambar 1). Peluang keberhasilan proses hibridisasi antara $S$. macrophylla dan S. stenoptera akan lebih tinggi dibanding antara S. macrophylla dan S. pinanga.

Belum banyak informasi mengenai kedekatan genetik $S$. gysbertsiana dan $S$. macrophylla, sehingga sulit menemukan referensi yang mutahir. Beberapa pustaka melaporkan bahwa S. gysbertsiana merupakan nama lain S. macrophylla (Soerianegara dan Lemmens, 1994; Newman dkk., 1996). Pada penelitian ini diperoleh bahwa meskipun beberapa allele merupakan allele bersama antara S. gysbertsiana dan S. macrophylla namun susunan maupun frekuensi allele dua jenis tersebut berbeda. Data genetik tersebut menunjukkan bahwa meskipun mempunyai jarak genetik yang lebih rendah/dekat dibandingkan dengan dua jenis Shorea lainnya yaitu $S$. stenoptera dan $S$. pinanga namun stuktur allele $S$. gysbertsiana dan $S$. macrophylla berbeda satu sama lain. Namun demikian, untuk memastikan perbedaan dua 
jenis Shorea tersebut masih membutuhkan penelitian lebih lanjut.

\section{KESIMPULAN}

Empat penanda mikrosatelit yaitu Shc-1, Shc-2, Shc-7 dan Shc-9 telah tersedia untuk empat jenis Shorea penghasil tengkawang yaitu S. gysbertsiana, S. macrophylla, S. pinanga dan S. stenoptera yang dikembangkan melalui metode seleksi primer dari S. curtisii. Empat penanda tersebut mempunyai tingkat keragaman genetik yang tinggi dan mempunyai nilai inbreeding yang tidak nyata, kecuali di lokus Shc-1 pada S. pinanga. Selain itu, penelitian ini menunjukkan bahwa S.gysbertsiana berkerabat dekat dengan $S$. macrophylla, sedangkan $S$. pinanga berkerabat dengan S. stenoptera. Oleh karena penanda mikrosatelit yang telah dikembangkan mempunyai tingkat keragaman genetik yang cukup tinggi dan tidak nyata menyimpang dari hukum keseimbangan HardyWeinberg, maka penanda tersebut dapat digunakan untuk analisis genetik populasi maupun sistem perkawinan pada empat jenis Shorea tersebut.

\section{DAFTAR PUSTAKA}

Dow, B.D., Ashley, M.V. 1998. High levels of gene flow in bur Oak revealed by paternity analysis using microatellites. The Journal of Heredity 89 (1): 6270.

Echt, C.S., Vendramin, G.G., Nelson, C.D., Marquardt, P. 1999. Microsatellite DNA as shared genetic markers among conifer species. Can. J. For. Res. 29: 365-371.
Lee, S.L. Tani, N., NG, K.K.S, Tsumura, Y. 2004. Isolation and characterization of 20 microsatellite loci for an important tropical tree Shorea leprosula (Dipterocarpaceae) and their applicability to $S$. parvifolia. Molecular Ecology Notes 4: 222-225.

Mariette, S., Chagne, D., Decroocq, S., Vendramin, G.G., Lalanne, C., Madur, D. Plomion, C. 2001. Microsatellite markers for Pinus pinaster Ait. Ann. For. Sci., 58: 203-206.

Moriguchi, Y., Iwata, H., Ujino-Ihara, T., Yoshimaru, K., Taira, H., Tsumura, Y. 2003. Development and characterization of microsatellite markers for Cryptomeria japonica D. Don. Theor. Appl. Genet. 106: 751-758.

Nei, M., Tajima, F., Tateno, Y. 1983. Accuracy of estimated phylogenetic trees from molecular data. J Mol Evol. 19: 153-170.

Newman, M.F., Burgess, P.F., Whitmore, T.C. 1996. Manual of dipterocarps for foresters. Borneo Island light hardwoods: Anisoptera, Parashorea, Shorea (red, white and yellow meranti. Royal Botanic Garden Edinburgh, United Kingdom. 275 pp.

Peakall, R., Smouse P.E. 2006. GENALEX 6: genetic analysis in Excel. Population genetic software for teaching and research. Molecular Ecology Notes 6: 288-295.

Rahman, M.H., Rajora, O.P. 2002. Microsatellite DNA fingerprinting, differentiation, and genetic relationship of clones, cultivars, and varieties of six poplar species from three sections of the genus Populus. Genome 45: 1083-1094.

Rimbawanto, A., Shiraishi, S.,Watanabe, A., Widyatmoko, A.Y.P.B.C. 1996. Tropical Plantation Establishment Improving Productivity through Genetic Practices. Procceding International Seminar. Yogyakarta.

Shiraishi, S., Watanabe, A. 1995. Identification of chloroplast genome between Pinus densiflora Sieb et Zucc and $P$. thumbergii Parl based on the polymorphism in $r b c \mathrm{~L}$ gene. Journal of Japanese Forestry Society 77: 429-436.

Soerianegara, I., Lemmens, R.H.M. 1994. Plant Resources of South-East Asia No. 5(1) Timber trees: Major commercial timbers. PROSEA, Bogor, Indonesia.

Ujino, T., Kawahara, T., Tsumura, Y., Nagamitsu, T., Yoshimaru, H., Ratnam, W. 1998. Development and polymorphism of simple sequence repeat DNA markers for Shorea curtisii and other Dipterocarpaceae species. Heredity 81: 422-428. 